\title{
Elastic moduli, damping and modulus of rupture changes in a high alumina refractory castable due to different types of thermal shock
}

\author{
A. H. A. PEREIRA', A. R. C. NASCIMENTO' ', C. C. D. EXPOSITO' ', L. T. MARTINS' ${ }^{1}$, T. TONNESEN² , J. A. RODRIGUES' \\ ${ }^{1}$ Federal University of São Carlos, DEMa, Materials' Microstructure Design Group, GEMM - São Carlos, SP, Brazil \\ ${ }^{2}$ RWTH-Aachen, GHI, Aachen, Germany
}

\begin{abstract}
The work herein verifies the changes of the elastic moduli, damping and modulus of rupture (MOR) of a high alumina refractory castable due to heating, cooling and heating-cooling thermal shock damage.

Twelve prismatic specimens were prepared for the tests and divided into four groups. The thermal shocks were performed on three groups, each containing three specimens having abrupt temperature changes of $1100^{\circ} \mathrm{C}$ during heating in the first group, during cooling in the second and during heating followed by cooling in the third group. The fourth group, which was taken as a reference did not receive any thermal shock. The elastic moduli were measured after each thermal shock cycle. After 10 cycles, the MOR, the damping and the damping dependence on excitation amplitude were measured at room temperature for all specimens.

The elastic moduli showed a similar decrease and the damping a similar increase due to the cooling and heating-cooling thermal shocks. The heating thermal shocks caused no significant changes on the elastic moduli and damping. However, the MOR appeared to be sensitive to the heating thermal shock. This work also shows that the damping for the studied refractory castable is non-linear (i.e., amplitude of excitation sensitive) and that this non-linearity increases when the damage level rises.
\end{abstract}

Keywords: refractories, thermal shock, mechanical properties, non-destructive tests, Young's modulus.

Alteraciones de los módulos elásticos, del amortiguamiento y del módulo de rotura provocado por diferentes tipos de choques térmicos en material refractario moldeable de alta alúmina

En este trabajo se investigaron las alteraciones de los módulos elásticos dinámicos, del amortiguamiento y del módulo de rotura (MOR) de un material refractario moldeable de alta alúmina después de recibir choques térmicos de calentamiento, enfriamiento y calentamiento seguido de enfriamiento (calentamiento-enfriamiento).

Para ello se prepararon doce cuerpos prismáticos dividiéndolos en cuatro grupos. Los choques térmicos se le aplicaron a sólo tres grupos, cada uno con tres muestras.

Al primer grupo se le aplicó un cambio brusco de temperatura de $1100{ }^{\circ} \mathrm{C}$ en calentamiento, en enfriamiento al segundo grupo y calentamiento seguido de enfriamiento al tercer grupo. El cuarto grupo no recibió choque térmico. Los módulos elásticos se midieron después de cada ciclo de choque térmico.

Después de 10 ciclos, el MOR, el amortiguamiento, y la dependencia de la amortiguación de la amplitud de la excitación fueron caracterizados a temperatura ambiente en todos los cuerpos de prueba.

Como resultado se obtuvo que los cuerpos sometidos a cambios bruscos de temperatura por enfriamiento y calentamientoenfriamiento presentaran una reducción similar en los módulos elásticos y aumento similar en la amortiguación mientras que el calentamiento no causó cambios significativos en estos parámetros. Sin embargo, el MOR pareció ser sensible a los cambios bruscos de temperatura por calentamiento.

Este estudio también mostró que la amortiguación para el material refractario estudiado no es lineal y que este comportamiento no lineal se acentúa con el daño por choque térmico.

Palabras chave: Refractarios, choque térmico, propiedades mecánicas, ensayos no destructivos, módulo de Young.

\section{INTRODUCTION}

In the engineering of refractory materials for highly demanding thermal shock applications, nucleation of cracks, propagation and arrest are the main factors in the thermal shock resistance optimization (1). Thermal shock induces crack nucleation and propagation through thermal stress (2-4) resulting in a decrease of elastic moduli and mechanical strength and in an increase of damping (5-9). Taking this into account, it is interesting to understand in more depth the differences between cooling and heating thermal shock types, since both are present in applications of refractories.

To evaluate the thermal shock damage, the most common ways are the retained module of rupture and the retained dynamic Young's modulus characterizations after heatingcooling thermal shock cycles (1,5-7). Damping, shear modulus and Poisson's ratio are also used for that purpose, however to a lesser extent. Young's modulus is proportional to the 
mechanical strength (9) and influenced by the length and density of the cracks (2). The damping quantifies the material's mechanical energy loss rate and is strongly correlated with the frictional area between the walls of the cracks and microcracks, and consequently also with the crack configuration, length and density (5-7).

In this work, a high alumina refractory castable was characterized considering Young's modulus $(\mathrm{E})$, the shear modulus $(G)$, Poisson's ratio $(v)$ and damping $(\xi)$ by the impulse excitation technique, and with regards the modulus of rupture (MOR) by a three-point bending test for different damage levels induced by heating, cooling, and heatingcooling thermal shocks. The application of different types of thermal shock intended to verify if the heating thermal shock would be able to promote damage and its contribution to the heating-cooling thermal shock for the studied material. The aim of applying different types of thermal shock was also to find out if those property changes are coherent among them no matter the type of thermal shock, since different crack configurations are expected depending on the thermal shock type. It is known that the cracks will appear most likely in the surface region of the specimen under cooling thermal shocks and in the bulk for the case of heating thermal shocks.

In addition, the influence of the mechanical excitation intensity applied to the specimens in the case of the damping measurements was also investigated.

\section{MATERIAL AND METHODS}

\subsection{Material}

The material investigated was a high alumina castable. The composition is described in Table I. Citric acid and FS40 deflocculant were used as dispersion additives. Twelve prismatic bars of $25 \mathrm{~mm} \times 25 \mathrm{~mm} \times 150 \mathrm{~mm}$ in dimension were moulded under vibration. The bars were calcined at $450{ }^{\circ} \mathrm{C}$ for 6 hours followed by sintering at $1500{ }^{\circ} \mathrm{C}$ for 12 hours. After firing, the rougher surface of the specimens was ground (the rougher surface is the one which was not in contact with the mould surfaces).

The twelve prismatic bars were divided into four groups of three specimens each: one as the reference group and three to be subjected to the different types of thermal shocks.

\subsection{Thermal shock procedure}

Three thermal shock types were applied: heating thermal shock, cooling thermal shock and heating-cooling thermal shock.

The heating thermal shocks were carried out by heating the specimens one at a time suddenly from room temperature to $1125{ }^{\circ} \mathrm{C}$, a temperature change of $1100{ }^{\circ} \mathrm{C}$. To apply this thermal shock, the specimens at room temperature were introduced suddenly into a muffle at $1125{ }^{\circ} \mathrm{C}$, where they remained for 15 minutes and then cooled at $3{ }^{\circ} \mathrm{C} / \mathrm{min}$ until $100{ }^{\circ} \mathrm{C}$. Next, the specimens were removed from the muffle to cool to room temperature.

In the case of the cooling thermal shocks, firstly the specimens were heated from room temperature up to $1125^{\circ} \mathrm{C}$ in a muffle at a rate of $3{ }^{\circ} \mathrm{C} / \mathrm{min}$. After $15 \mathrm{~min}$ for equilibrium at that temperature, the specimens were suddenly removed from the muffle to cool in air.

The heating-cooling thermal shocks were performed by heating the specimens suddenly up to $1125^{\circ} \mathrm{C}$ and after $15 \mathrm{~min}$ at that temperature the specimens were suddenly cooled down to room temperature in air. The heating-cooling thermal shock is a usual procedure for thermal shock damage evaluation.

\subsection{Elastic moduli characterization}

To perform the elastic moduli characterization, the equipment Sonelastic (ATCP Physical Engineering, São Carlos, Brazil) was used, which applies the mechanical impulse excitation technique in agreement with the ASTM C1548 (10). In this technique, Young's modulus is calculated from the bar's flexural resonance, the shear modulus from the torsional one, and Poisson's ratio from $\mathrm{E}$ and $\mathrm{G}$ via the elastic relationship $v=[(E /(2 G))-1]$ through an interactive algorithm that can also refine the Young's modulus calculation. The method is based on the Piquet-equations that correlate the natural vibration frequencies, the specimen dimensions, the specimen mass and the elastic moduli (11).

The resonance frequencies are excited by a controlled mechanical impulse and the acoustic response is captured by a microphone and processed by software. The mechanical impulse is provided by an electromagnetic actuator controlled by an electronic driver which supplies an electrical pulse of $10 \mathrm{~ms}$ in duration at an variable level between 1 and 11 Volts.

TABLE I: CASTABLE COMPOSITION (WEIGHT-PERCENTAGE NOT INCLUDING THE WATER AND ADDITIVES)

\begin{tabular}{lll}
\hline Components & Composition in wt- $\%$ & Grain size (mm) \\
\hline Matrix and aggregates & 12.5 Reactive alumina & $0.000-0.045$ \\
& 10.0 Tabular alumina & $0.000-0.300$ \\
& 10.0 Tabular alumina & $0.200-0.600$ \\
& 10.0 Tabular alumina & $0.500-1.000$ \\
& 17.5 Tabular alumina & $1.000-3.000$ \\
\hline Cement & 35.0 Tabular alumina & \\
\hline \multirow{2}{*}{ Additives } & 5.00 Secar 71, calcium aluminates & \\
& 0.10 Deflocculant FS 40 \\
\hline Water & 0.03 Citric acid & \\
\hline
\end{tabular}


The excitation intensity was adjusted in an arbitrary range from 0 to $100 \% ; 100 \%$ corresponding to the maximum voltage possible for the excitation before the occurrence of double hitting of the actuator tip and $0 \%$ to the threshold level for the actuator tip touches the specimen (minimum voltage possible for the excitation). The sample holder applies the required mechanical boundary conditions. Figure 1 presents the sample holder and the electromagnetic actuator used for the elastic moduli and damping characterization; the specimen [1] is supported under the fundamental flexural nodes [2] by wires [3], the excitation is carried out by the electromagnetic actuator [4] and the microphone [5] picks up the acoustic response of the specimen.

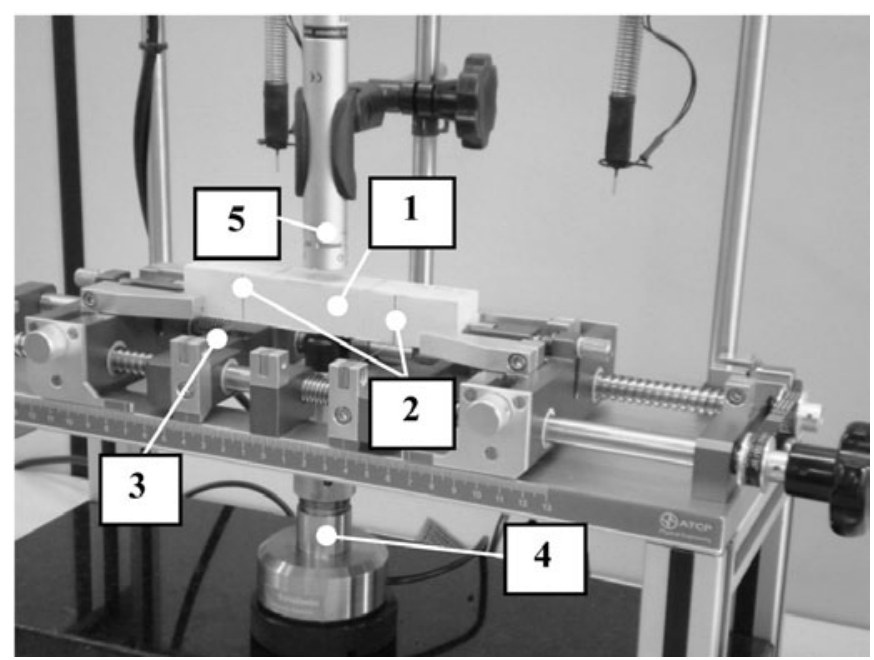

Figure 1: Apparatus applied to dynamic elastic moduli and damping characterizations.

The dynamic elastic moduli were characterized nondestructively after the specimens' preparation and after each thermal shock cycle. As a reference, each group of specimens was characterized before any thermal shock with the specimens dried at $120{ }^{\circ} \mathrm{C}$ for 2 hours. This was needed because during the grinding, the specimens come in contact with a coolant mixture of water and soluble oil. To verify if the specimen orientation had some influence on the elastic moduli results, the specimens were characterized positioned in the same way as when they received the thermal shock and also rotated $90^{\circ}$ around the longitudinal axis.

\subsection{Damping characterization}

The damping was characterized with the same equipment used for the elastic modulus measurements. It applies the logarithm decay method improved with frequency domain analysis and with the Levenberg-Marquardt fitting algorithm for noisy environments (12-14). The transitory acoustic response of the specimen to the impulse excitation contains the specimen resonant frequencies and the damping ratio information.

The damping of the fundamental flexural resonance was characterized non-destructively at room temperature before and after the thermal shock cycles with the specimens previously dried at $120^{\circ} \mathrm{C}$ for 2 hours.

\subsection{Mechanical strength characterization}

The modulus of rupture (MOR) of the reference group without any thermal shock and of the heating, cooling and heating-cooling groups after 10 thermal shock cycles were measured using the 3-point bending test according to the DIN EN 993-6 standard. It was used a mechanical testing machine (MTS Corporation, USA) under a controlled load of 0.15 $\mathrm{MPa}$ / s with a span of $125 \mathrm{~mm}$. The MOR-values were used as an independent measurement to verify the occurrence or not of the damage.

\section{RESULTS AND DISCUSSION}

The results obtained for the retained Young's modulus are presented in Figure 2 and for the retained shear modulus in Figure 3. The retained moduli values are the ratio of the value after the thermal shock to the value before any thermal shock times one hundred to obtain the percentage. The results were obtained with impulse excitation intensity at $20 \%$. The error bars in Figures 2, 3 and 4 correspond to the standard deviation (each point corresponds to the average results of three samples).

The absolute values of the moduli after preparation and before the thermal shock cycles are presented in Table II. The samples were chosen randomly, even so a difference in the average values of the properties occurred. This difference was neglected and probably occurs due to the specimen size, the coarse microstructure and the small number of specimens.

The elastic moduli show a significant percentage decrease after the initial thermal shock cycles for the cooling and heating-cooling thermal shocks, probably because the temperature variation of $1100^{\circ} \mathrm{C}$ is higher than the material's first critical temperature. This decrease was slightly higher for the heating-cooling than for the cooling thermal shocks. On the other hand, the heating thermal shock was not severe enough to cause damage considering this measurement as the only criterion for that. It is known from the factors which affect the thermal shock resistance (3) that the thermal stress on heating is half of that of the cooling. Additionally, when the

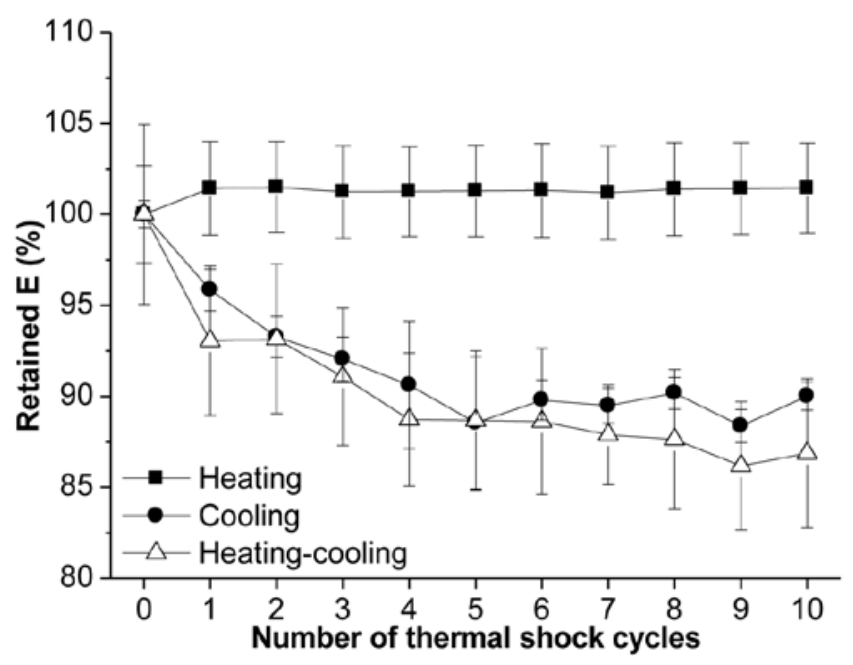

Figure 2: Retained Young's modulus, in percentage, after thermal shock cycles with $\Delta \mathrm{T}=1100^{\circ} \mathrm{C}$. 
TABLE II: INITIAL MEAN VALUES OF ELASTIC MODULI FOR THE FOUR DIFFERENT SPECIMEN GROUPS BEFORE ANY THERMAL SHOCK.

\begin{tabular}{cccc}
\hline Group & E (GPa) & G (GPa) & n (ad.) \\
\hline Heating & $142.9 \pm 6.4$ & $58.9 \pm 1.1$ & $0.21 \pm 0.06$ \\
Cooling & $141.8 \pm 3.6$ & $58.8 \pm 0.7$ & $0.21 \pm 0.04$ \\
Heating-cooling & $132.1 \pm 9.1$ & $56.4 \pm 1.9$ & $0.17 \pm 0.07$ \\
Reference & $141.0 \pm 7.3$ & $60.7 \pm 0.7$ & $0.16 \pm 0.04$ \\
Reference* & $142.3 \pm 7.4$ & $61.3 \pm 1.5$ & $0.16 \pm 0.07$
\end{tabular}

* After heat treatment at $550{ }^{\circ} \mathrm{C}$ for 30 minutes.

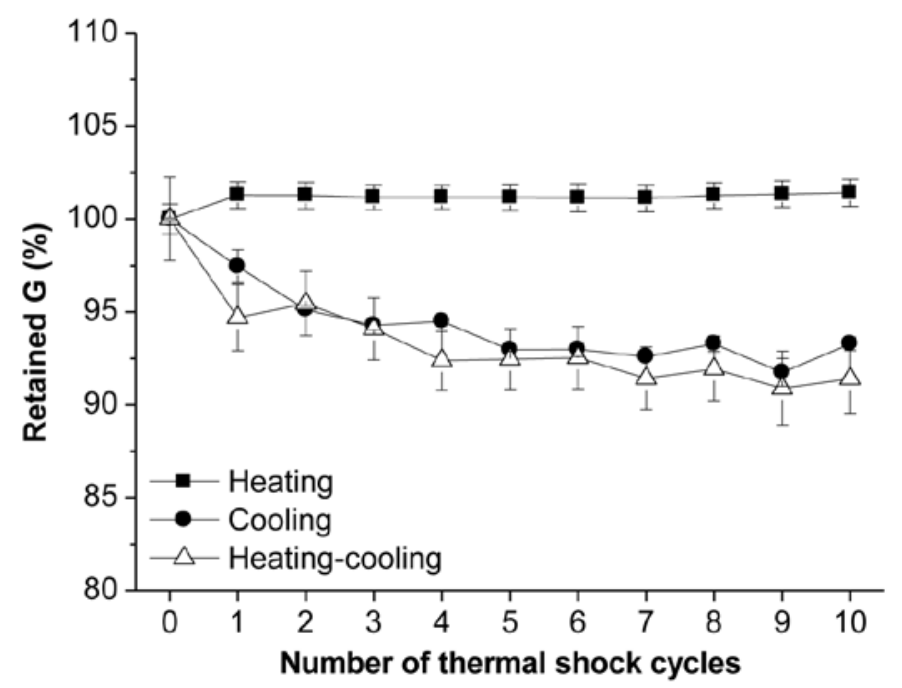

Figure 3: Retained shear modulus, in percentage, after thermal shock cycles with $\Delta \mathrm{T}=1100^{\circ} \mathrm{C}$.

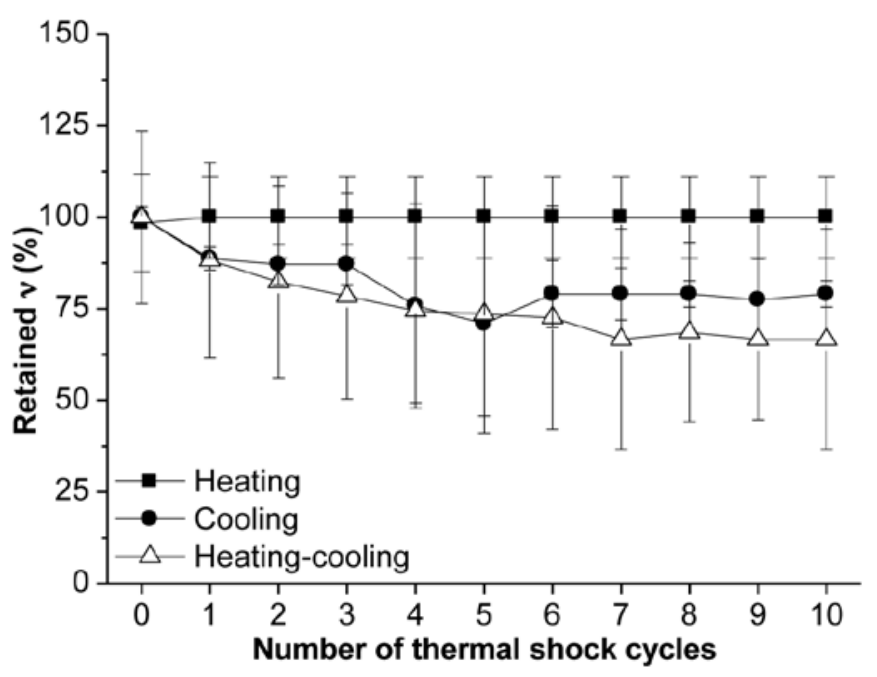

Figure 4: Retained Poisson's ratio, in percentage, after thermal shock cycles with $\Delta \mathrm{T}=1.100^{\circ} \mathrm{C}$. sample is heated, the surface is under compression and when cooled, it is under tensile stresses (in the bulk the opposite occurs). The ceramic materials are more resistant under compression than under tensile stresses. Therefore, one may expect the crack formation primarily on the surface region and a thermal shock resistance when heated many times higher than when cooled, which explains the obtained results. In fact, Young's modulus and the shear modulus seem to have increased slightly after the first heating thermal shock cycle for the heating group. The reason for this can be the influence of the coolant mixture absorbed during the grinding process and eliminated during the heating up to $1100{ }^{\circ} \mathrm{C}$. A similar occurrence was also observed in the reference group and is associated with the material structural non-linearity $(15,16)$. As shown in Table II, after heat treatment at $550{ }^{\circ} \mathrm{C}$ for 30 minutes the Young's modulus and the shear modulus of the reference group slightly increased. For the retained values calculations it was used the results obtained before the heat treatment with the specimens dried at $120^{\circ} \mathrm{C}$ for 2 hours.

After a certain number of thermal cycles, the $E$ and $G$ retained values tended to stabilize (with regards the specimens from the heating-cooling and cooling groups). Since the thermal shock severity was kept constant $\left(\Delta \mathrm{T}=1100^{\circ} \mathrm{C}\right)$, with the crack initiation and propagation, the material becomes more thermal shock damage resistant and the damage induced by each thermal shock cycle gradually becomes lower.

Both the Young's modulus and the shear modulus become almost stable as the number of cycles increases, although they have different retained levels: the Young's modulus decreases proportionally more than the shear modulus. This disparity is reflected in the calculation of Poisson's ratio that is presented in Figure 4. It is possible that the thermal shocks tendency to induce cracks primarily at the specimen surfaces affects the material's stiffness isotropy. In this case, the calculated Poisson's ratio loses its initial physical meaning, however its variations can be considered as an indicator that the specimen shifts from the isotropic to the anisotropic one. This is an important aspect of the behavior of the Poisson's ratio as an indicator of damage. Negative values of this property can be obtained for severely damaged specimens as shown in the work of Rodrigues, Villaboim and Pandolfelli (17).

The results obtained for the damping are presented in Figure 5. The damping measurements did not detect significant damage in the case of heating thermal shocks, but detected similar damage level in the case of cooling and heating-cooling thermal shocks. These damping results are in agreement with the results from the elastic moduli 
measurements. In Figure 6, the damping dependence on the excitation intensity is presented.

The excitation intensity influence on the damping values presented in Figure 6 indicates that the damping for all groups is sensitive to the amplitude of vibration. However, the cooling and heating-cooling groups are two times more sensitive than the reference and heating groups. This strong amplitude influence indicates the presence of non-linear damping mechanisms and the intensification of these mechanisms with the damage caused by thermal shock. The non-linear damping mechanisms are directly correlated with the presence of defects and cracks (18). Owing to the larger area of frictional surfaces, the damping effect is more intensive and, in turn, also its non-linear behavior. This is due to the increase in the number of frictional defects with hysteretic behavior (19). Therefore, when the influence of the excitation intensity is not considered, this could bring significant systematic errors to the damping measurements.

Concerning specimen orientation during elastic moduli and damping measurements, no significant influence on the results was noted. This specimen orientation means its position relative to the position it occupied when the thermal shock was applied to it. The characterizations were performed with the specimens oriented in the same way as for the thermal shock situation and rotated $90^{\circ}$ around the longitudinal axis.

Figure 7 shows a macro photograph of the sandpapered surface of one specimen from the cooling group after 10 thermal shock cycles. It was pigmented with Fucsina.

The formation of cracks in the specimens subjected to cooling and heating-cooling thermal shocks was confirmed visually at the surface and was primarily in the matrix and the interface aggregate-matrix, as shown in Figure 7. No transaggregate cracks were observed. In the specimens subjected to heating thermal shock it was not possible to observe cracks on the surface.

Figure 8 shows the behavior of the MOR-values of the three groups that received 10 cycles of thermal shock and the reference group, which was not submitted to thermal shock.

The MOR-results confirm the overall behavior shown by the elastic moduli and damping (Figures 2, 3 and 5), however apparently the heating thermal shock affects the values of

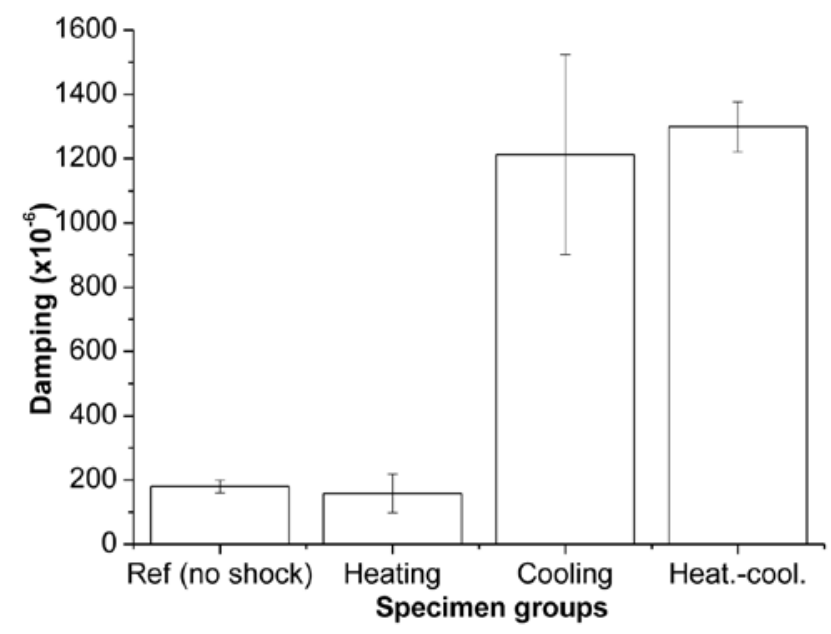

Figure 5: Average damping of the specimen groups after 10 thermal shock cycles with $\Delta \mathrm{T}=1100^{\circ} \mathrm{C}$. The reference group was not submitted to any thermal shock.

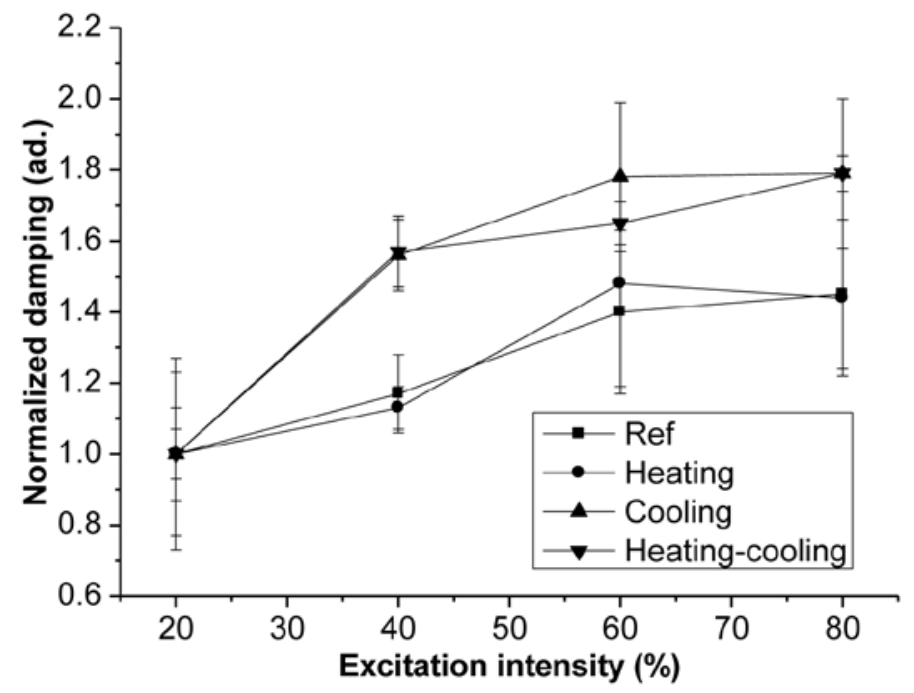

Figure 6: Normalized average damping of the specimen groups after 10 thermal shock cycles $\left(\Delta \mathrm{T}=1100^{\circ} \mathrm{C}\right)$ as a function of the excitation intensity.

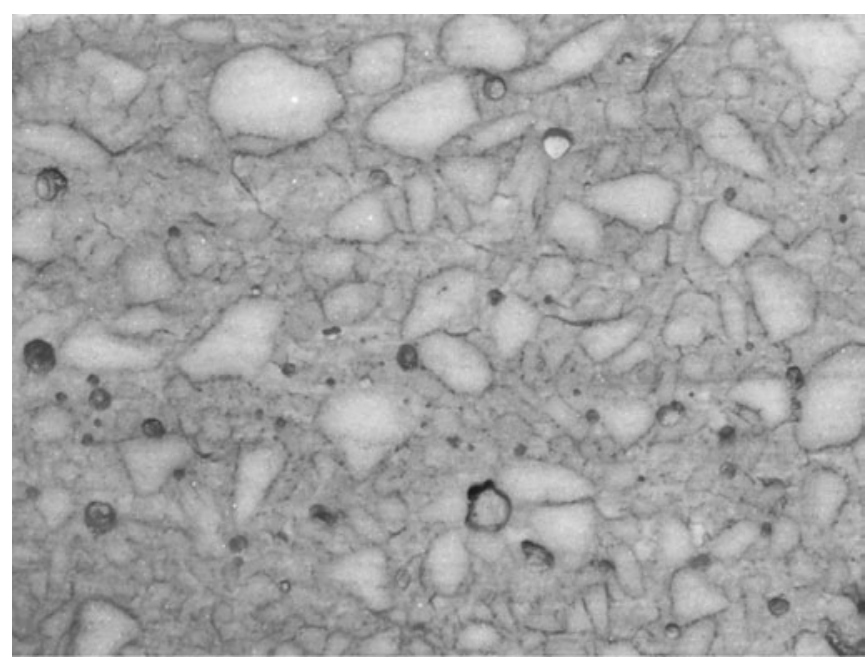

Figure 7: Macro photograph of the sandpapered surface of a specimen from the cooling group after 10 thermal shock cycles.

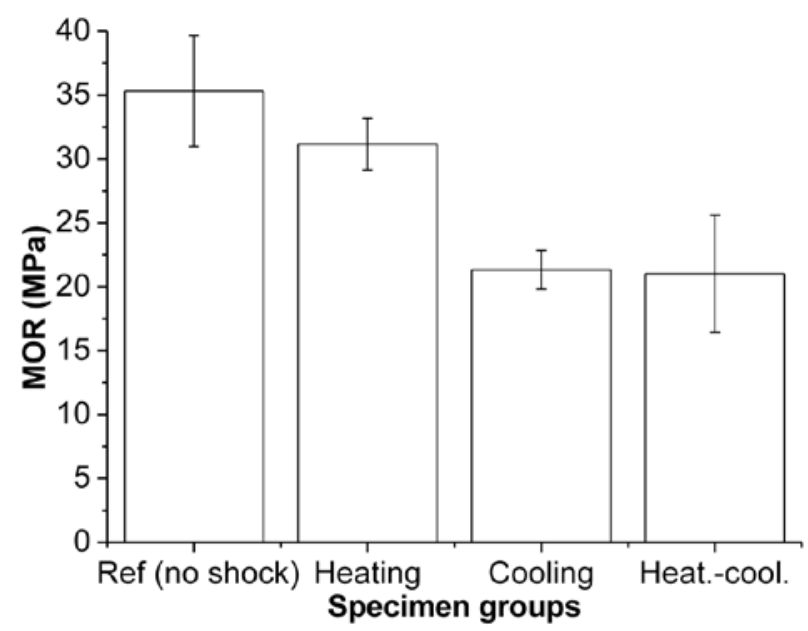

Figure 8: MOR-values of the specimen groups after 10 thermal shock cycles of each type. The reference group (Ref) was not submitted to any thermal shock. 
MOR, although there is an overlap of the error bars in relation to the reference group. The heating thermal shocks seem to have reduced the MOR values (compared to the reference group), which was not the case for E, G and damping. The configuration of cracks and micro-cracks in the specimens submitted to heating thermal shocks probably was such that it slightly affected the MOR-values but did not affect the elastic moduli and damping values.

\section{CONCLUSIONS}

The work showed that for the material studied and thermal shock conditions, the cooling thermal shock is the primary cause of damage and that the heating thermal shock leads to little or no damage. However, when cooling and heating thermal shocks are applied in a sequential way (heating-cooling thermal shock), the consequent damage seems to be slightly bigger than just the cooling thermal shock.

This work also shows that the coherence among the changes of the MOR-values, the elastic modulus and the damping are sensitive to the configuration of the cracks in the specimen.

Additionally, it was observed that the damping evolution for the studied castable is non-linear and that this nonlinearity increases when the thermal shock damage level rises. In the same way as the absolute damping value, this nonlinearity also seems to be a potential indicator of the thermal shock damage severity. One must be careful with damping measurements in respect to accuracy if the material presents non-linear behavior.

\section{ACKNOWLEDGEMENTS}

The authors are grateful to CNPq (Projects 301073/20066, 303061/2009-0, and 141868/2008-2), CAPES (PROBRAL 258/07 and BEX 3926/08-7), PIBIC/UFSCar/CNPq, FINEP (Project 4028-6) and DAAD (Deutscher Akademischer Austausch Dienst) for the financial support.

\section{REFERENCES}

(1) D. P. H. Hasselman. "Unified Theory of Thermal Shock Fracture Initiation and Crack Propagation in Brittle Ceramics". Journal of the American Ceramic Society, 82[11] 600-604 (1969).

(2) C. Baudín. Revisión: “Resistencia de los refractarios al choque térmico I: Aproximación termoelástica y criterio de balance energético" Bol. Soc. Esp. Ceram. Vidr., 32, (4), 237-244 (1993).

(3) W. D. Kingery, "Factors Affecting Thermal Stress Resistance of Ceramic Materials". Journal of the American Ceramic Society, 38[1] 1-15 (1955).

(4) C. Baudín. Revisión: "Resistencia de los refractarios al choque térmico II: Teoría unificada de Hasselman" Bol. Soc. Esp. Ceram. Vidr., 32, (5), 293298 (1993).

(5) T. Tonnesen and R. Telle. "Thermal Shock Damage in Castables: Microstructural Changes and Evaluation by a Damping Method". Ceramic Forum International, 84[9] E132-E136 (2007).

(6) A. H. A. Pereira, G. M. Fortes, B. Schickle, T. Tonnesen, B. Musolino, C. D. Maciel, J. A. Rodrigues. "Correlation between changes in mechanical strength and damping of a high alumina refractory castable progressively damaged by thermal shock". Cerâmica, 56 311-314 (2010).

(7) J. A. Coppola. "Thermal-Shock Damage in SiC". Journal of the American Ceramic Society, 56[4] 214-218 (1973)

(8) M. Ortiz. "A Constitutive Theory for the Inelastic Behavior of Concrete" Mechanics of Materials, 4 67-93 (1985)

(9) A. Fawzy and C. E. Semler. "Prediction of Refractory Strength Using Nondestructive Sonic Measurements". Am. Ceram. Soc. Bull., 64[12] 15551558 (1985)

(10) ASTM C1548 - 02(2007), "Standard Test Method for Dynamic Young's Modulus, Shear Modulus, and Poisson's Ratio of Refractory Materials by Impulse Excitation of Vibration". American Society for Testing and Materials (2007)

(11) G. Pickett. "Equations for Computing Elastic Constants from Flexional and Torsional Resonant Frequencies of Vibration of Prisms and Cylinders". ASTM Proceedings, 45 846-865 (1945)

(12) B. C. Musolino, A. H. A. Pereira, J. A. Rodrigues, W. Endo, C. D. Maciel. "Algoritmo para determinação do coeficiente de amortecimento de materiais pela técnica da excitação por impulso". In: Anais XVIII Congresso Brasileiro de Automática, 2010, p. 4972-4978 URL: http:// www.opec-eventos.com.br/cba2010/ ?pag=txt\&id=28

(13) L. Finschi. "An Implementation of the Levenberg-Marquardt Algorithm". Technical Report, Institute for Operations Research, ETH Zürich (1996) URL: http: / / www.ifor.math.ethz.ch/staff/ finschi/LevMar/LevMar.pdf

(14) M. Karjalainen, P. Antsalo, A. Mäkivirta, T. Peltonen and V. Välimäki. "Estimation of Modal Decay Parameters from Noisy Response Measurements". J. Audio Eng. Soc., 50[11] 867-878 (2002).

(15) K. E. A. Van Den Abeele, J. Carmeliet, P. A. Johnson, B. Zinszner. “Influence of water saturation on the nonlinear elastic mesoscopic response in Earth materials and the implications to the mechanism of nonlinearity". J. of Geophysical Research, 107[b6] 2121-2111 (2002).

(16) A. H. A. Pereira, A. R. C. Nascimento, L. T. M. Martins, D. Y. Miyaji, J. A. Rodrigues. "Influência da umidade na caracterização do amortecimento e do módulo de Young dinâmico de um concreto". In: 54 Congresso Brasileiro de Cerâmica, 2010, Foz do Iguaçu. Anais do 53 Congresso Brasileiro de Cerâmica, 2010.

(17) J. A. Rodrigues, E. L. G. Villaboim, V. C. Pandofelli. “Behavior of thermal shock damage in refractory castables based on their elastic moduli and Poisson's ratio". Proceedings of the 46th. International Colloquium on Refractories, 12th-13th. November 2003, Aachen, Germany, 100-103 (2003).

(18) K. V. D. Abeele and J. Visscherb. "Damage assessment in reinforced concrete using spectral and temporal nonlinear vibration techniques". Cement and Concrete Research, 30[9] 1453-1464 (2000).

(19) K. R. McCall, R. A. Guyer. "Equation of state and wave propagation in hysteretic nonlinear elastic materials". J. of Geophysical Research, 99[B12], 23,887-23,897 (1994). 